\title{
Soil chemical characteristics, biomass production and levels of nutrient and heavy metals in corn plants according to doses of steel slag and limestone ${ }^{1}$
}

\author{
Luiz Carlos Santos Caetano ${ }^{2 *}$, Luiz Carlos Prezotti ${ }^{3}$, Bevaldo Martins Pacheco ${ }^{2}$, Rogério Carvalho Guarçoni ${ }^{4}$
}

$10.1590 / 0034-737 X 201663060018$

\begin{abstract}
Steel slag presents potential for neutralizing the soil acidity instead of limestone and for supplying nutrients for plants. The objective of this work was to study the effect of steel slag on soil chemical characteristics, biomass production, and contents of nutrients and of heavy metals on dry matter of corn plants. The levels of $\mathrm{P}, \mathrm{K}, \mathrm{Na}, \mathrm{Ca}, \mathrm{Mg}$, $\mathrm{Cu}, \mathrm{Fe}, \mathrm{Zn}, \mathrm{Mn}, \mathrm{Si}, \mathrm{Cd}, \mathrm{Cr}, \mathrm{Pb}$, and $\mathrm{Ni}$ were determined in steel slag and limestone (for comparison purposes) and the growth of corn plants under increasing doses of slag and limestone ( 0 to $\left.10 \mathrm{tha}^{-1}\right)$ was evaluated. Steel slag presented higher levels of P, Fe, Zn, Mn, and Si when compared with limestone. No difference was found in the content of heavy metals of slag and limestone, except for $\mathrm{Cr}$, which was higher in the slag. Limestone provided the greatest increase of soil $\mathrm{pH}$ over time. Slag increased the content of $\mathrm{P}, \mathrm{Si}$, and soil micronutrient, while limestone was more efficient in increasing the content of Mg. The levels of heavy metals in the soil increased with the application of slag, but they remained below critical level within agricultural parameters. Slag and limestone presented a similar effect on the increase of the initial production of corn biomass. The levels of heavy metals in dry matter of corn plants under increasing doses of slag and limestone were below the critical levels of the toxicity of these elements on most plants.
\end{abstract}

Key words: soil fertility; solid waste; plant nutrition; limestone; Zea mays L.

\section{RESUMO}

\section{Características químicas do solo, produção de biomassa e teores de nutrientes e metais pesados em plantas de milho em função de doses de escória e de calcário}

A escória de aciaria apresenta potencial para neutralizar a acidez do solo em substituição ao calcário e fornecer nutrientes para as plantas. O objetivo deste trabalho foi estudar o efeito da escória de aciaria nas características químicas do solo, na produção de biomassa e nos teores de nutrientes e metais pesados na matéria seca de plantas de milho. Foram determinados os teores de P, K, Na, Ca, Mg, Cu, Fe, Zn, Mn, Si, Cd, Cr, Pb e Ni na escória e no calcário (efeito comparativo) e avaliaram-se o crescimento de plantas de milho submetidas às doses crescentes de escória e de calcário $\left(0\right.$ a 10 t ha $\left.^{-1}\right)$. A escória apresentou maiores teores dos elementos P, Fe, Zn, Mn e Si quando comparada ao calcário. Não houve diferença nos teores de metais pesados da escória e do calcário, com exceção do Cr, que foi superior na escória. O calcário proporcionou maior elevação do $\mathrm{pH}$ do solo ao longo do tempo. A escória elevou o teor de P, micronutrientes e Si do solo sendo o calcário mais eficiente na elevação do teor de $\mathrm{Mg}$. Os teores de metais pesados no solo aumentaram com a aplicação da escória, mas permaneceram abaixo dos níveis considerados críticos para a agricultura. A escória e o calcário apresentaram efeito semelhante no aumento da produção inicial de biomassa do milho. Os teores de metais pesados na matéria seca das plantas de milho submetidas às doses de escória e calcário foram inferiores aos níveis críticos para a toxidade desses elementos na maioria das plantas.

Palavras-chave: fertilidade do solo; resíduo sólido; nutrição de planta; Zea mays L.

\footnotetext{
Submitted on November $06^{\text {th }}, 2014$ and accepted on June 13 $3^{\text {th }}, 2016$. 'This study was financied by Arcelor Mittal Tubarão.

${ }^{2}$ Incaper - Instituto Capixaba de Pesquisa, Assistência Técnica e Extensão Rural, Cachoeiro de Itapemirim, Espírito Santo, Brazil. luizcaetano@incaper.es.gov.br; bevaldo@incaper.es.gov.br ${ }^{3}$ Incaper - Instituto Capixaba de Pesquisa, Assistência Técnica e Extensão Rural, Vitória, Espírito Santo, Brazil. prezotti@incaper.s.gov.br

${ }^{4}$ Incaper - Instituto Capixaba de Pesquisa, Assistência Técnica e Extensão Rural, Domingos Martins, Espírito Santo, Brazil. rogerio.guarconi@incaper.es.gov.br

*Corresponding author: luizcaetano@incaper.es.gov.br
} 


\section{INTRODUCTION}

Slags are products resulting from industrial processes aimed at obtaining pig iron first, and then for steel. Steel slag is generated in the steelmaking process, resulting from the transformation of liquid pig iron into steel. The acronym LD is due to the fact that the steel is produced in the LD Linz-Donawitz-type oxygen converter (Arcelor Mittal Tubarão, 2016).

Brazil is the sixth leading producer of pig iron in the world, with an annual production of about 25 million tons. The state of Minas Gerais is the largest producer, accounting for more than a half of all pig iron and steel domestically produced. The Brazilian steel industry currently generates approximately six million tons of steel slag per year (Ramos et al., 2016). In the state of Espírito Santo, Arcelor Mittal Tubarão produces about $86.2 \mathrm{~kg}$ of this slag per ton of liquid steel, resulting in approximately 415 thousand tons of slag per year (Arcelor Mittal Tubarão, 2016).

Because of the large quantity produced and the lack of destination for slag, steelmakers are required to store them in open-air yards, forming huge mountains, which occupy large areas. The accumulation of these materials in these places has become a serious environmental problem due to the possibility of leaching of chemical compounds, caused by exposure to rains, in which groundwater table contamination may occur.

In general, tropical soils present high acidity and low levels of nutrients, mainly $\mathrm{Ca}, \mathrm{Mg}, \mathrm{P}$ and micronutrients, which are essential to the maintenance of crop productivity. Studies carried out by Prado \& Fernandes (2000 and 2003) have shown that slag, when applied to soil, increases $\mathrm{pH}$ and reduces $\mathrm{H}+\mathrm{Al}$. Increases in $\mathrm{P}$ availability were observed by Prado et al. (2002) and a rise in the contents of $\mathrm{Si}, \mathrm{Ca}$ and $\mathrm{Mg}$, higher disease resistance and productivity increases in $\mathrm{Si}$ accumulating crops such as rice and sugarcane were observed by Winslon (1992).

For its use in agriculture, slag must be crushed and screened. When applied to the soil, it promotes neutralization of acidity by dissociation of $\mathrm{CaSiO}_{3}$ and $\mathrm{MgSiO}_{3}$ into $\mathrm{Ca}, \mathrm{Mg}$ and $\mathrm{SiO}_{3}$ since the latter reacts with $\mathrm{H}^{+}$in the soil solution, forming $\mathrm{H}_{4} \mathrm{SiO}_{4}$. The reactivity of the slag varies according to the particle size, dose and time of contact with the soil (Alcarde, 2005).

The application of slag in soils at doses equivalent to the adsorption capacity of the chemical elements in the CEC will allow the neutralization of the acidity of the soil with similar effect by limestone and, additionally, the supply of some nutrients to the plants.

The objective of this work was to study the effect of steel slag compared to limestone on soil chemical characteristics, biomass production and contents of nutrient and heavy metals in the dry matter of corn plants.

\section{MATERIAL AND METHODS}

Samples from LD steel slag from the Arcelor Mittal Tubarão Steel Industry, located in the municipality of Serra, state of Espírito Santo, (20 14' 16,6" S; 40 13' 59,5"W), were sieved in 2-mm mesh and after that, their contents of $\mathrm{P}, \mathrm{K}, \mathrm{Na}, \mathrm{Mg}, \mathrm{Cu}, \mathrm{Fe}, \mathrm{Zn}, \mathrm{Mn}$ and $\mathrm{Si}$ were determined according to the methodology described by the Ministério da Agricultura, Pecuária e Abastecimento (1988) and the contents of $\mathrm{Cd}, \mathrm{Cr}, \mathrm{Pb}$ and $\mathrm{Ni}$ were set by the method according to Embrapa (1997). For comparison, the same analyzes were performed using limestone.

Contents of $\mathrm{CaO}, \mathrm{MgO}$ and PRNT obtained in the analysis were $23.6 \%, 7.0 \%$ and $45 \%$ for steel slag and $29.0 \%$, $9.0 \%$ and $73 \%$ for limestone, respectively.

In a study conducted in a greenhouse, volumes of 2 $\mathrm{dm}^{3}$ of Oxissol, collected from the $0-20 \mathrm{~cm}$ depth, were incubated in pots with seven increasing doses of steel slag and limestone: $0 ; 0.5 ; 1.0 ; 2.0 ; 4.0 ; 6.0 ; 8.0$ and $10 \mathrm{t} \mathrm{ha}^{-1}$ and maintained at $70 \%$ of moisture of the field capacity until $\mathrm{pH}$ stabilization. After that, soil samples were collected from the pots for determination of $\mathrm{pH}$ and contents of $\mathrm{P}, \mathrm{K}$, $\mathrm{Na}, \mathrm{Ca}, \mathrm{Mg}, \mathrm{Al}, \mathrm{V}, \mathrm{Zn}, \mathrm{Fe}, \mathrm{Mn}, \mathrm{Cu}, \mathrm{B}, \mathrm{Si}$ and heavy metals $\mathrm{Cd}, \mathrm{Cr}, \mathrm{Pb}$ and $\mathrm{Ni}$, according to methods described by Embrapa (2009). The experiment was conducted in a completely randomized design with three replicates. The $\mathrm{pH}$ of the soil was also evaluated on days at $0,3,7,10,17$ and 24 after application, using a completely randomized design with three replications in the split plot in time design, in which the plots were constituted by increasing doses of slag and limestone. The experimental data were submitted to analysis of variance and the regression models were adjusted using the SAEG statistical analysis system (Ribeiro Júnior \& Melo, 2009).

Afterwards, ten corn seeds were planted in these containers and, after germination, thinning was carried out, maintaining five plants per pot. Top-dressing fertilization consisted of $200 \mathrm{mg} \mathrm{dm}^{-3} \mathrm{~N}$ (urea, $45 \% \mathrm{~N}$ ) and $130 \mathrm{mg} \mathrm{dm}^{-3}$ of $\mathrm{K}\left(\mathrm{KCl}, 60 \% \mathrm{~K}_{2} \mathrm{O}\right)$, split into three doses equal to 5, 10 and 15 days after germination. After 30 days, the plants were cut close to the soil and the aerial part was dried in a forced ventilation oven at $70{ }^{\circ} \mathrm{C}$ until achieving constant weight. After determining the dry matter mass of the aerial part of the corn plants in each plot, chemical analyzes of the plant material were carried out to determine the nutrient and heavy metal contents, according to the methods described by Embrapa.

The data of all the characteristics, except those of $\mathrm{pH}$ of the soil as a time function after the application of doses of slag and limestone, were submitted to regression analysis; the models were tested using the F-test and the regression parameters the T-test. For the soil $\mathrm{pH}$ as a time function after slag and limestone application, preliminary 
analysis of variance was performed according to the design employed (DIC with three replications in the scheme of split plot in time) and afterwards, the unfolding of the dosetime interaction to study $\mathrm{pH}$ behavior as time function for each dose of slag and limestone. In addition, the regression models were tested using the $\mathrm{F}$ test and the regression parameters by the t-test.

\section{RESULTS AND DISCUSSION}

When analyzing the elements in slag and limestone (Table 1), higher values were observed in the slag, mainly for P, Na, Cu, Fe, Zn, Mn and Si. The elements P, Fe, Mn and $\mathrm{Si}$ should be highlighted as they showed considerably higher values than those found in limestone. On the other hand, limestone presented higher contents of $\mathrm{K}, \mathrm{Ca}$ and $\mathrm{Mg}$. Among the heavy metals, content of $\mathrm{Cr}$ stood out since it was as much as 100 times higher in the slag than in the limestone. The higher Si content in the slag is an interesting feature due to its beneficial effect in the increase in the resistance to water stress in several crops, as observed by Korndörfer et al. (2011). In a study by Lima et al. (2011), the application of silicon via nutrient solution promoted higher values in all the growth variables and diminished the toxic effects of $\mathrm{NaCl}$ on the growth of corn seedlings.

The values of $\mathrm{pH}$ and nutrient contents in the soil after incubation with slag and limestone are listed in Tables 2 and 3 . In relation to the $\mathrm{pH}$, the regression equations showed that limestone $(\mathrm{PRNT}=73 \%)$ presented greater efficiency in the reduction of soil acidity than slag (PRNT $=45 \%$ ), with an increase of 0.1352 units of $\mathrm{pH}$ for each ton applied, against an increase of 0.0897 units of $\mathrm{pH}$ for each applied ton of slag.

A significant increase in the $\mathrm{P}$ content in the soil, provided by slag application, was found, switching from 1 $\mathrm{mg} \mathrm{dm} \mathrm{da}^{-3}$ at zero dose to $7 \mathrm{mg} \mathrm{dm}^{-3}$ at the dose of $10 \mathrm{tha}^{-1}$, while limestone application did not provide any significant increases in P content in the soil (Tables 2 and 3). This fact is explained by the higher content of phosphorus in the slag, as observed in Table 1. According to the applied doses of slag, they supplied from 0.8 to $16 \mathrm{mg}$ of $\mathrm{P} \mathrm{kg}^{-1}$ soil.
In the analysis, the extractor (Melich-1) solubilized 1 to 7 $\mathrm{mg}$ of $\mathrm{P} \mathrm{kg}^{-1}$ soil. With the application of slag doses, an increase in content of $\mathrm{K}$ occurred only at the dose of $10 \mathrm{t}$ $\mathrm{ha}^{-1}$, with a quadratic behavior by the regression equation. By applying limestone doses, the regression equation showed linear growth of the $\mathrm{K}$ content, although higher levels were achieved with 6 and $10 \mathrm{tha}^{-1}$ of the corrective. The significant superiority in the $\mathrm{K}$ content of the limestone (Table 1) was not confirmed at the same proportion in the values obtained in the soil analysis (Table 3), despite the increasing effect of the applied doses. The levels of $\mathrm{Ca}$ in the soil were increasing both for slag and for limestone, reflecting the element contents in the products. For $\mathrm{Mg}$, a significant raise in its content in the slag incubated soil was observed from the dose of $4.0 \mathrm{t} \mathrm{ha}^{-1}$ dose, while in the soil incubated with limestone, a similar increase was observed even at the lower doses, reflecting the difference in content in the correctives shown in Table 1.

The content of $\mathrm{Al}^{3+}$ decreased as doses of slag and limestone was applied, being completely neutralized at the dose of $10 \mathrm{t} \mathrm{ha}^{-1}$ of both materials (Tables 2 and 3). Base saturation (V) increased as slag and limestone were applied, with higher final values with application of limestone, which presented a higher PRNT value. In a study conducted by Corrêa et al. (2007), steel slag increased base saturation and the availability of $\mathrm{NO}_{3}, \mathrm{Ca}$ and $\mathrm{Mg}$ up to the depth of $40 \mathrm{~cm}$ in the soil, in only three months of reaction.

Contents of the micronutrients and Si were influenced only by the addition of slag to the soil (Table 2), reflecting the superiority of the contents of such elements in this material (Table 1). Manganese was the micronutrient most influenced by slag application, increasing from $5.0 \mathrm{mg} \mathrm{dm}^{-3}$ to $43.0 \mathrm{mg} \mathrm{dm}^{-3}$, which is an increase of approximately $800 \%$. Content of $\mathrm{Si}$ in the soil increased as much as twice with the use of slag.

The values of $\mathrm{pH}$ measured after application of slag and limestone on days $0,3,7,10,17$ and 24 after incubation showed increasing behavior over time (Table 4), since $\mathrm{pH}$ neutralization reaction continues with application time. At doses of 0.5 and $1.0 \mathrm{tha}^{-1}$, the effects of materials at soil $\mathrm{pH}$ were similar with close slope coefficients of the regression

Table 1: Contents of macronutrients, micronutrients, silicon, sodium and heavy metals in steel slag and limestone

\begin{tabular}{|c|c|c|c|c|c|c|c|}
\hline \multirow{2}{*}{ Product } & $\mathbf{P}$ & $\mathbf{K}$ & $\mathrm{Ca}$ & Mg & $\mathrm{Na}$ & $\mathbf{C u}$ & $\mathrm{Fe}$ \\
\hline & \multicolumn{4}{|c|}{$\mathrm{g} \mathrm{kg}^{-1}$} & \multicolumn{3}{|c|}{$\mathrm{mg} \mathrm{kg}^{-1}$} \\
\hline Slag & 3.200 & 0.228 & 205.200 & 35.600 & 216 & 12 & 117.500 \\
\hline \multirow[t]{3}{*}{ Limestone } & 0.270 & 0.526 & 237.600 & 58.400 & 58 & 2 & 1.652 \\
\hline & Zn & Mn & Si & Cd & $\mathrm{Cr}$ & $\mathbf{P b}$ & $\mathbf{N i}$ \\
\hline & \multicolumn{7}{|c|}{$\mathrm{mg} \mathrm{kg}^{-1}$} \\
\hline Slag & 48 & 19.900 & 12.960 & 2.6 & 703 & 50 & 37 \\
\hline Limestone & 8 & 52 & 700 & 2.6 & 7 & 40 & 23 \\
\hline
\end{tabular}


equation. At higher doses, the coefficients of the regression equations pointed to a larger limestone effect. At the dose of $10 \mathrm{t} \mathrm{ha}^{-1}$, only the effect by the limestone was found on soil $\mathrm{pH}$. The difference in PRNT between the materials had decisively contributed to the achievement of this result.
Effects of slag on the increase of soil $\mathrm{pH}$ were also obtained by Corrêa et al. (2007) and Prezotti \& Martins (2012).

The average values of $\mathrm{Cd}$ content in the soil (Table 5) were influenced by the application of slag, reaching a maximum value of $0.10 \mathrm{mg} \mathrm{dm}^{-3}$ with the application of 7.9

Table 2: Average values for the chemical characteristics of the soil incubated with increasing doses of steel slag and estimated regression equations of the effect of increasing doses of steel slag on soil chemical characteristics

\begin{tabular}{|c|c|c|c|c|c|c|c|c|c|}
\hline Dose $\left(t h^{-1}\right)$ & $\mathbf{0}$ & 0.5 & 1 & 2 & 4 & 6 & 10 & Regression equation & $\mathbf{R}^{2}$ \\
\hline$\overline{\mathrm{pH}}$ & 4.9 & 5.0 & 5.0 & 5.1 & 5.3 & 5.5 & 5.8 & $\mathrm{pH}=4.9274+0.0897 * * \mathrm{x}$ & $0.99 * *$ \\
\hline $\mathrm{P}\left(\mathrm{mg} \mathrm{dm}^{-3}\right)$ & 1 & 2 & 2 & 2 & 4 & 6 & 7 & $\mathrm{P}=1.3537+0.618^{* * \mathrm{x}}$ & $0.94 * *$ \\
\hline $\mathrm{K}^{+}\left(\mathrm{mg} \mathrm{dm} \mathrm{m}^{-3}\right)$ & 15 & 16 & 14 & 14 & 13 & 13 & 20 & $K=15.785-1.528 x+0.1934 * x^{2}$ & $0.93 * *$ \\
\hline $\mathrm{Na}^{+}\left(\mathrm{mg} \mathrm{dm}^{-3}\right)$ & 6 & 7 & 8 & 9 & 7 & 8 & 10 & & \\
\hline $\mathrm{Ca}^{2+}\left(\mathrm{cmol}_{\mathrm{c}} \mathrm{dm}^{-3}\right)$ & 0.3 & 0.3 & 0.5 & 0.9 & 1.6 & 2.3 & 2.9 & $\mathrm{Ca}=0.1538+0.4316 \mathrm{x}-0.0154 * * \mathrm{x}^{2}$ & $0.99 * *$ \\
\hline $\mathrm{Mg}^{2+}\left(\mathrm{cmol}_{\mathrm{c}} \mathrm{dm}^{-3}\right)$ & 0.1 & 0.1 & 0.1 & 0.1 & 0.2 & 0.2 & 0.6 & $\mathrm{Mg}=0.1072-0.0142 \mathrm{x}+0.0063^{*} * \mathrm{x}^{2}$ & $0.98 * *$ \\
\hline $\mathrm{Al}^{3+}\left(\mathrm{cmol}_{\mathrm{c}} \mathrm{dm}^{-3}\right)$ & 1.2 & 1.1 & 1.0 & 0.8 & 0.5 & 0.2 & 0.0 & $\mathrm{Al}=1.2101-0.2261 \mathrm{x}+0.00104 * * \mathrm{x}^{2}$ & $1.00 * *$ \\
\hline $\mathrm{V}(\%)$ & 9 & 8 & 15 & 24 & 37 & 52 & 63 & $\mathrm{~V}=6.0774+9.6672 \mathrm{x}-0.3925 * * \mathrm{x}^{2}$ & $0.99 * *$ \\
\hline $\mathrm{Zn}^{2+}\left(\mathrm{mg} \mathrm{dm}^{-3}\right)$ & 0.4 & 0.3 & 0.4 & 0.3 & 0.4 & 0.5 & 1.0 & $\mathrm{Zn}=0.3751-0.0397 \mathrm{x}+0.0102 * * \mathrm{x}^{2}$ & $0.98 * *$ \\
\hline $\mathrm{Fe}^{3+}\left(\mathrm{mg} \mathrm{dm}^{-3}\right)$ & 171 & 131 & 161 & 141 & 165 & 178 & 210 & $\mathrm{Fe}=145.91+5.7721 * \mathrm{x}$ & $0.66^{*}$ \\
\hline $\mathrm{Mn}^{3+}\left(\mathrm{mg} \mathrm{dm}^{-3}\right)$ & 5 & 7 & 10 & 13 & 25 & 34 & 43 & $\mathrm{Mn}=3.9838+6.0626 \mathrm{x}-0.2121 * * \mathrm{x}^{2}$ & $0.99 * *$ \\
\hline $\mathrm{Cu}^{2+}\left(\mathrm{mg} \mathrm{dm}^{-3}\right)$ & 0.3 & 0.3 & 0.3 & 0.3 & 0.3 & 0.3 & 0.4 & $\mathrm{Cu}=0.3064-0.0112 \mathrm{x}+0.002 * * \mathrm{x}^{2}$ & $0.96 * *$ \\
\hline $\mathrm{B}\left(\mathrm{mg} \mathrm{dm} \mathrm{m}^{-3}\right)$ & 0.22 & 0.26 & 0.24 & 0.21 & 0.18 & 0.20 & 0.29 & $\mathrm{~B}=0.2494-0.0267 \mathrm{x}+0.0031 * \mathrm{x}^{2}$ & $0.79 * *$ \\
\hline $\operatorname{Si}\left(\mathrm{mg} \mathrm{dm}^{-3}\right)$ & 47 & 52 & 58 & 57 & 70 & 88 & 124 & $\mathrm{Si}=49.164+4.3563 \mathrm{x}+0.3146^{* *} \mathrm{x}^{2}$ & $0.99 * *$ \\
\hline
\end{tabular}

$*$ and ** Significant at the levels of $5 \%$ and $1 \%$ of probability by the $\mathrm{F}$ or $\mathrm{t}$ tests, respectively.

Table 3: Average values for the chemical characteristics of the soil incubated with increasing doses of limestone and estimated regression equations of the effect of increasing doses of limestone on soil chemical characteristics

\begin{tabular}{|c|c|c|c|c|c|c|c|c|c|}
\hline Dose $\left(\mathrm{t} \mathrm{ha}^{-1}\right)$ & $\mathbf{0}$ & 0.5 & 1 & 2 & 4 & 6 & 10 & Regression equation & $\mathbf{R}^{2}$ \\
\hline $\mathrm{pH}$ & 4.9 & 5.0 & 5.2 & 5.3 & 5.6 & 5.8 & 6.3 & $\mathrm{pH}=4.989+0.1352 * * \mathrm{x}$ & $0.98 * *$ \\
\hline $\mathrm{P}\left(\mathrm{mg} \mathrm{dm} \mathrm{m}^{-3}\right)$ & 1 & 1 & 1 & 1 & 1 & 1 & 1 & & \\
\hline $\mathrm{K}^{+}\left(\mathrm{mg} \mathrm{dm}^{-3}\right)$ & 15 & 14 & 14 & 13 & 12 & 22 & 22 & $\mathrm{~K}=12.958+0.0061 * \mathrm{x}$ & $0.61 *$ \\
\hline $\mathrm{Na}^{+}\left(\mathrm{mg} \mathrm{dm}^{-3}\right)$ & 6 & 8 & 7 & 7 & 7 & 6 & 10 & & \\
\hline $\mathrm{Ca}^{2+}\left(\mathrm{cmol}_{\mathrm{c}} \mathrm{dm}^{-3}\right)$ & 0.3 & 0.4 & 0.5 & 0.9 & 1.6 & 2.4 & 3.3 & $\mathrm{Ca}=0.1984+0.3965 \mathrm{x}-0.0083^{*} * \mathrm{x}^{2}$ & $1.00 * *$ \\
\hline $\mathrm{Mg}^{2+}\left(\mathrm{cmol}_{\mathrm{c}} \mathrm{dm}^{-3}\right)$ & 0.1 & 0.2 & 0.4 & 0.6 & 1.0 & 1.7 & 2.1 & $\mathrm{Mg}=0.0649-0.3082 \mathrm{x}+0.0101 * * \mathrm{x}^{2}$ & $0.99 * *$ \\
\hline $\mathrm{Al}^{3+}\left(\mathrm{cmol}_{\mathrm{c}} \mathrm{dm}^{-3}\right)$ & 1.2 & 0.9 & 0.7 & 0.5 & 0.1 & 0.1 & 0.0 & $\mathrm{Al}=1.0748-0.3073 \mathrm{x}+0.0203 * * \mathrm{x}^{2}$ & $0.96^{* *}$ \\
\hline $\mathrm{V}(\%)$ & 9 & 18 & 23 & 37 & 51 & 64 & 80 & $\mathrm{~V}=11.204+12.377 \mathrm{x}-0.5551 * * \mathrm{x}^{2}$ & $1.00 * *$ \\
\hline $\mathrm{Zn}^{2+}\left(\mathrm{mg} \mathrm{dm}{ }^{-3}\right)$ & 0.4 & 0.3 & 0.3 & 0.3 & 0.4 & 0.4 & 0.4 & & \\
\hline $\mathrm{Fe}^{3+}\left(\mathrm{mg} \mathrm{dm}^{-3}\right)$ & 171 & 112 & 187 & 185 & 156 & 168 & 168 & & \\
\hline $\mathrm{Mn}^{3+}\left(\mathrm{mg} \mathrm{dm}^{-3}\right)$ & 5 & 4 & 5 & 5 & 4 & 6 & 6 & & \\
\hline $\mathrm{Cu}^{2+}\left(\mathrm{mg} \mathrm{dm}^{-3}\right)$ & 0.3 & 0.2 & 0.3 & 0.3 & 0.3 & 0.3 & 0.2 & & \\
\hline $\mathrm{B}\left(\mathrm{mg} \mathrm{dm} \mathrm{dm}^{-3}\right)$ & 0.22 & 0.22 & 0.17 & 0.20 & 0.20 & 0.21 & 0.21 & & \\
\hline $\mathrm{Si}\left(\mathrm{mg} \mathrm{dm}^{-3}\right)$ & 47 & 29 & 36 & 26 & 50 & 45 & 54 & & \\
\hline
\end{tabular}

$*$ and $* *$ Significant at the levels of $5 \%$ and $1 \%$ of probability by the $\mathrm{F}$ or t tests, respectively.

Table 4: Regression equations of soil pH estimation as a function of time (in days) of application of steel slag and limestone doses

\begin{tabular}{lllll}
\hline $\begin{array}{l}\text { Dose of slag } \\
\text { or limestone }\left(\mathbf{t ~ h a}^{-1}\right)\end{array}$ & \multicolumn{1}{c}{ Slag effect } & $\mathbf{R}^{2}$ & \multicolumn{1}{c}{ Limestone effect } & $\mathbf{R}^{2}$ \\
\hline 0 & $\mathrm{pH}=4.9859+0.0129 \mathrm{x}^{* *}$ & $0.98^{* *}$ & $\mathrm{pH}=4.9859+0.0129 * * \mathrm{x}$ & $0.98^{* *}$ \\
0.5 & $\mathrm{pH}=5.0783+0.0136 \mathrm{x}^{* *}$ & $0.85^{* *}$ & $\mathrm{pH}=5.0018+0.0162^{* \mathrm{x}}$ & $0.79^{*}$ \\
1.0 & $\mathrm{pH}=5.0777+0.0153 \mathrm{x}^{* *}$ & $0.83^{*}$ & $\mathrm{pH}=5.0189+0.0162^{* *} \mathrm{x}$ & $0.97 * *$ \\
2.0 & $\mathrm{pH}=5.1189+0.0162 \mathrm{x}^{* *}$ & $0.97^{* *}$ & $\mathrm{pH}=5.176+0.0204^{* *} \mathrm{x}$ & $0.89^{* *}$ \\
4.0 & $\mathrm{pH}=5.3536+0.0144 \mathrm{x}^{* *}$ & $0.84^{* *}$ & $\mathrm{pH}=5.4736+0.0272^{*} \mathrm{x}$ & $0.68^{* *}$ \\
6.0 & $\mathrm{pH}=5.4771+0.017 \mathrm{x}^{* *}$ & $0.86^{* *}$ & $\mathrm{pH}=5.7119+0.0365^{*} \mathrm{x}$ & $0.76^{*}$ \\
10.0 & $\mathrm{pH}=5.6984+0.1009^{\mathrm{ns}} \mathrm{x}-0.0028^{\mathrm{ns}} \mathrm{x}^{2}$ & $0.56^{\mathrm{ns}}$ & $\mathrm{pH}=5.924+0.1611 \mathrm{x}-0.0047^{*} \mathrm{x}^{2}$ & $0.90^{*}$ \\
\hline
\end{tabular}

$*$ and $* *$ Significant at the levels of $5 \%$ and $1 \%$ of probability by the $\mathrm{F}$ or $\mathrm{t}$ tests, respectively. 
$\mathrm{t} \mathrm{ha}^{-1}$ of slag; however, the highest levels of such element were observed with the application of limestone, despite the same content of the element in the materials (Table 1). According to Cetesb (2005), the maximum allowed concentration of $\mathrm{Cd}$ in agricultural soils is $3.0 \mathrm{mg} \mathrm{dm}^{-3}$, therefore, much higher than those obtained with the applied doses of slag and limestone.

Content of $\mathrm{Cr}$ in the soil increased (Table 6) as doses of slag and limestone increased, with a raise of $0.0747 \mathrm{mg} \mathrm{dm}^{-3}$ of $\mathrm{Cr}$ per ton of slag against $0.0513 \mathrm{mg} \mathrm{dm}^{-3}$ of $\mathrm{Cr}$ per ton of limestone applied, a result compatible with the high $\mathrm{Cr}$ content in the slag (Table 1). Contents of $\mathrm{Pb}$ and $\mathrm{Ni}$ were influenced only by the application of slag, although they also increased with the application of limestone (Tables 5 and 6). Slag presented slightly higher contents of these elements (Table $1)$. These values are rather below those recommended by Cetesb (2005) for agriculture land use orientation in the state of São Paulo, that is, 180,150 and $70 \mathrm{mg} \mathrm{dm}^{-3}$ for $\mathrm{Pb}, \mathrm{Cr}$ and Ni, respectively. Corrêa et al. (2008) found no increase in soil availability for heavy metals, $\mathrm{Cd}, \mathrm{Cr}, \mathrm{Hg}, \mathrm{Pb}, \mathrm{Ni}$ and $\mathrm{As}$ by applying up to $8.0 \mathrm{t} \mathrm{ha}^{-1}$ of steel slag.
The raise in base saturation (V\%), the neutralization of the acidity and the availability of nutrients with the application of slag and limestone provided better growth of corn plants, reaching the maximum dry matter production of approximately $35 \mathrm{~g}$ at the dose equivalent to $7.0 \mathrm{t} \mathrm{ha}^{-1}$ of both materials (Figure 1). Prezotti \& Martins (2012) obtained an increase in sugarcane yield (cane plant and ratoon at field level) with the application of steel slag at doses ranging from 0.5 to 40.0 t ha $^{-1}$.

Contents of $\mathrm{N}$ and $\mathrm{P}$ in the dry matter of corn plants were reduced as doses of slag and limestone increased, probably due to the dilution effect, which occurs due to the rapid initial production of dry matter of the plants, resulting in a reduction proportional to the content of these elements in the plant tissues (Tables 6 and 7). For N, this effect was expected because of its inexistence in composition in both slag and limestone. For $\mathrm{P}$, a raise in the contents with the application of the slag was expected due to the presence of this element in its constitution. It is likely that the absorption rate of $\mathrm{P}$ was not sufficient to attend the initial metabolic demand of corn plants, leading

Table 5: Heavy metal content in the soil as a function of increasing doses of steel slag and limestone using the Mehlich-1 extractor and estimated regression equations of the effect of increasing doses of steel slag and limestone on the levels of heavy metals in the soil

\begin{tabular}{|c|c|c|c|c|c|c|c|c|c|}
\hline Dose $\left(\mathbf{t} \mathbf{h a}^{-1}\right)$ & $\mathbf{0}$ & 0.5 & 1 & 2 & 4 & 6 & 10 & Regression equation & $\mathbf{R}^{2}$ \\
\hline \multicolumn{10}{|c|}{ Slag } \\
\hline $\mathrm{Cd}\left(\mathrm{mg} \mathrm{dm}^{-3}\right)$ & 0.07 & 0.07 & 0.08 & 0.09 & 0.09 & 0.10 & 0.10 & $\mathrm{Cd}=0.0703+0.0079 \mathrm{x}-0.0005 * * \mathrm{x}^{2}$ & $0.93 * *$ \\
\hline $\mathrm{Cr}\left(\mathrm{mg} \mathrm{dm}^{-3}\right)$ & 0.48 & 0.80 & 0.82 & 0.71 & 0.81 & 0.92 & 1.46 & $\mathrm{Cr}=0.6062+0.0747 * * \mathrm{x}$ & $0.84 * *$ \\
\hline $\mathrm{Pb}\left(\mathrm{mg} \mathrm{dm}^{-3}\right)$ & 0.7 & 1.0 & 0.9 & 1.0 & 1.3 & 1.5 & 1.6 & $\mathrm{~Pb}=0.7706+0.1658 \mathrm{x}-0.0082 * * \mathrm{x}^{2}$ & $0.95 * *$ \\
\hline $\mathrm{Ni}\left(\mathrm{mg} \mathrm{dm}^{-3}\right)$ & 0.50 & 0.68 & 0.78 & 0.76 & 0.76 & 1.04 & 1.06 & $\mathrm{Ni}=0.6349+0.0483 * \mathrm{x}$ & $0.79 *$ \\
\hline \multicolumn{10}{|c|}{ Limestone } \\
\hline $\mathrm{Cd}\left(\mathrm{mg} \mathrm{dm}^{-3}\right)$ & 0.07 & 0.13 & 0.15 & 0.15 & 0.16 & 0.16 & 0.16 & & \\
\hline $\mathrm{Cr}\left(\mathrm{mg} \mathrm{dm}^{-3}\right)$ & 0.48 & 0.48 & 0.58 & 0.62 & 0.71 & 0.80 & 1.00 & $\mathrm{Cr}=0.4948+0.0513 * * \mathrm{x}$ & $0.98 * *$ \\
\hline $\mathrm{Pb}\left(\mathrm{mg} \mathrm{dm}^{-3}\right)$ & 0.7 & 1.7 & 1.8 & 1.7 & 1.5 & 1.0 & 1.4 & & \\
\hline $\mathrm{Ni}\left(\mathrm{mg} \mathrm{dm}^{-3}\right)$ & 0.50 & 1.35 & 1.27 & 1.37 & 1.37 & 1.37 & 1.37 & & \\
\hline
\end{tabular}

$*$ and ** Significant at the levels of $5 \%$ and $1 \%$ of probability by the $\mathrm{F}$ or t tests, respectively.

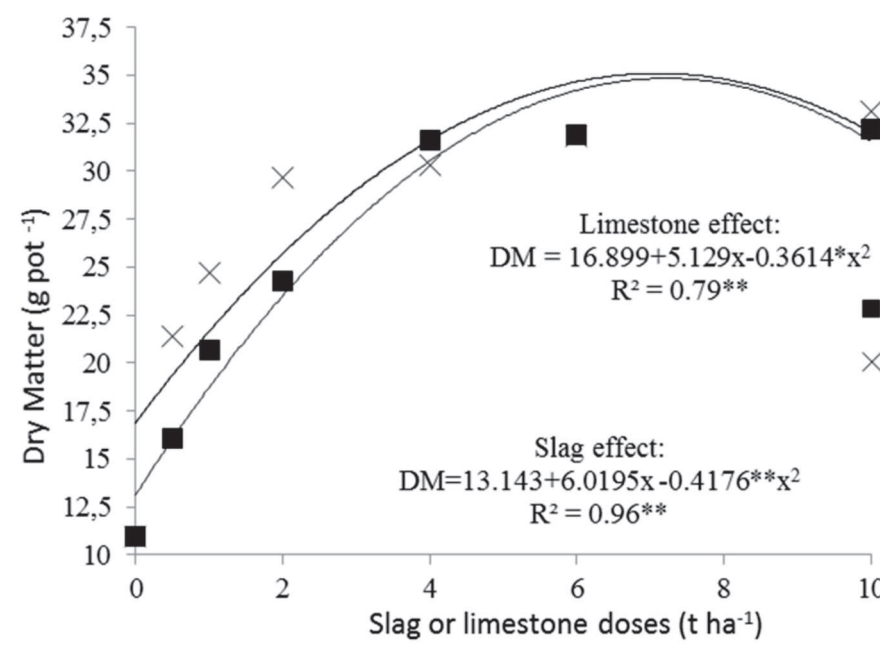

Figure 1: Dry matter production of corn plants acording to doses of steel slag and limestone. 
to the reduction of their contents in the tissues. Prezotti \& Martins (2012) observed an increase in the content of P in the tissues of sugarcane plants at the end of the crop cycle when submitted to increasing doses of slag.

Content of $\mathrm{K}$ in the aerial part of the corn plants decreased in relation to the zero dose with the doses of 0.5 to $4 \mathrm{t} \mathrm{ha}^{-1}$ of limestone, rising again at the two highest doses of the corrective, which resulted in the quadratic behavior of the regression equation (Table 7). At lower doses of limestone, the rapid increase in corn dry matter production probably did not allow the analysis to detect the increase in the nutrient content in its tissues.

Contents of $\mathrm{Ca}$ and $\mathrm{Mg}$ in the plant tissue (Tables 6 and 7) also increased with increasing doses of slag and limestone, with the highest $\mathrm{Ca}$ content obtained with application of slag and the $\mathrm{Mg}$ content obtained with limestone. Although it presented the lowest content of $\mathrm{Ca}$ in its composition (Table 1), slag yielded an increase of $0.1753 \mathrm{dag} \mathrm{kg}^{-1}$ of $\mathrm{Ca}$ in the dry matter of corn plants for each ton applied from $0.12335 \mathrm{dag} \mathrm{kg}^{-1}$ for each ton of limestone added to the soil. Because limestone presented higher content of $\mathrm{Mg}$ in its composition (Table 1), it provided a greater increase in the content of $\mathrm{Mg}$ in corn plants, reaching the maximum point of $1.376 \mathrm{dag}$ $\mathrm{kg}^{-1}$ of $\mathrm{Mg}$ at the dose of $6.664 \mathrm{tha}^{-1}$ when compared to the content of $0.722 \mathrm{dag} \mathrm{kg}^{-1}$ of $\mathrm{Mg}$ for the same dose of slag. In this case, no effect of dilution occurred, probably due to the greater availability of these elements in the soil, provided by the application of these materials. In addition, as an effect of the dilution by the rapid initial production of plant biomass, the contents of $S$ in the leaf dry matter were reduced as doses of slag and limestone increased.

Contents of $\mathrm{Zn}$ in the tissues of the aerial part of the plants decreased as doses of slag and limestone increased, with no significant differences between the effects of the

Table 6: Nutrient and silicon contents in dry matter of aerial part of corn plants grown in soil incubated with increasing doses of steel slag and estimated regression equations of the effect of increasing doses of steel slag on nutrient contents in the dry matter of aerial part of corn plants

\begin{tabular}{|c|c|c|c|c|c|c|c|c|c|}
\hline Dose $\left(\mathbf{t} \mathbf{h a}^{-1}\right)$ & $\mathbf{0}$ & 0.5 & 1 & 2 & 4 & 6 & 10 & Regression equation & $\mathbf{R}^{2}$ \\
\hline $\mathrm{N}\left(\right.$ dag kg $\left.^{-1}\right)$ & 5.5 & 5.2 & 5.5 & 5.2 & 5.0 & 5.0 & 3.4 & $\mathrm{~N}=5.3487+0.0436 \mathrm{x}-0.0233 * * \mathrm{x}^{2}$ & $0.95 * *$ \\
\hline $\mathrm{P}\left(\right.$ dag $\left.\mathrm{kg}^{-1}\right)$ & 0.59 & 0.56 & 0.44 & 0.33 & 0.25 & 0.24 & 0.19 & $P=0.5693-0.1044 x+0.0068 * * x^{2}$ & $0.94 * *$ \\
\hline $\mathrm{K}^{+}\left(\operatorname{dag~kg}^{-1}\right)$ & 0.86 & 0.86 & 0.88 & 0.96 & 0.78 & 0.76 & 0.96 & & \\
\hline $\mathrm{Ca}^{2+}\left(\right.$ dag kg $\left.^{-1}\right)$ & 0.05 & 0.36 & 0.57 & 0.55 & 1.17 & 1.08 & 2.02 & $\mathrm{Ca}=0.24+0.1753 * * \mathrm{x}$ & $0.94 * *$ \\
\hline $\mathrm{Mg}^{2+}\left(\right.$ dag $\left._{\mathrm{kg}}{ }^{-1}\right)$ & 0.17 & 0.23 & 0.24 & 0.32 & 0.51 & 0.63 & 1.02 & $\mathrm{Mg}=0.1655+0.083 * *_{\mathrm{x}}$ & $1.00 * *$ \\
\hline $\mathrm{S}^{2-}\left(\mathrm{dag} \mathrm{kg}^{-1}\right)$ & 0.51 & 0.52 & 0.38 & 0.36 & 0.30 & 0.24 & 0.20 & $S=0.5033-0.07 x+0.004 * * x^{2}$ & $0.93 * *$ \\
\hline $\mathrm{Zn}^{2+}\left(\mathrm{mg} \mathrm{kg}^{-1}\right)$ & 47 & 49 & 37 & 30 & 26 & 21 & 18 & $\mathrm{Zn}=47.212-7.4057 \mathrm{x}+0.455^{*} * \mathrm{x}^{2}$ & $0.93 * *$ \\
\hline $\mathrm{Fe}^{3+}\left(\mathrm{mg} \mathrm{kg}^{-1}\right)$ & 221 & 622 & 555 & 773 & 692 & 539 & 322 & & \\
\hline $\mathrm{Mn}^{3+}\left(\mathrm{mg} \mathrm{kg}^{-1}\right)$ & 89 & 316 & 263 & 326 & 238 & 146 & 245 & & \\
\hline $\mathrm{Cu}^{2+}\left(\mathrm{mg} \mathrm{kg}^{-1}\right)$ & 3 & 3 & 3 & 4 & 3 & 3 & 4 & & \\
\hline $\mathrm{B}\left(\mathrm{mg} \mathrm{kg}^{-1}\right)$ & 13 & 24 & 24 & 25 & 17 & 26 & 16 & & \\
\hline $\mathrm{Si}\left(\mathrm{mg} \mathrm{kg}^{-1}\right)$ & 50 & 40 & 30 & 50 & 150 & 110 & 100 & & \\
\hline
\end{tabular}

$*$ and $* *$ Significant at the levels of $5 \%$ and $1 \%$ of probability by the $\mathrm{F}$ or $\mathrm{t}$ tests, respectively.

Table 7: Contents of nutrients and silicon in dry matter of aerial part of corn plants grown in the soil incubated with increasing doses of limestone and estimated regression equations of the effect of increasing doses of limestone on nutrient contents in the dry matter of aerial part of corn plants

\begin{tabular}{|c|c|c|c|c|c|c|c|c|c|}
\hline Dose $\left(t^{h} \mathbf{h}^{-1}\right)$ & $\mathbf{0}$ & 0.5 & 1 & 2 & 4 & 6 & 10 & Regression equation & $\mathbf{R}^{2}$ \\
\hline $\mathrm{N}\left(\right.$ dag kg $\left.^{-1}\right)$ & 5.5 & 4.5 & 4.7 & 4.4 & 4.4 & 4.3 & 3.3 & $\mathrm{~N}=4.968-0.1564{ }^{*} \mathrm{x}$ & $0.76^{*}$ \\
\hline $\mathrm{P}\left(\right.$ dag kg $\left.^{-1}\right)$ & 0.59 & 0.41 & 0.30 & 0.31 & 0.27 & 0.21 & 0.16 & $\mathrm{P}=0.428-0.0318^{*} \mathrm{x}$ & $0.65^{*}$ \\
\hline $\mathrm{K}\left(\right.$ dag kg $\left.\mathrm{kg}^{-1}\right)$ & 0.86 & 0.78 & 0.73 & 0.66 & 0.75 & 0.86 & 1.48 & $\mathrm{~K}=0.8227-0.0877 \mathrm{x}-0.0154 * * \mathrm{x}^{2}$ & $0.99 * *$ \\
\hline $\mathrm{Ca}\left(\right.$ dag kg $\left.^{-1}\right)$ & 0.05 & 0.35 & 0.51 & 0.77 & 0.73 & 0.78 & 1.59 & $\mathrm{Ca}=0.2682+0.1235 * \mathrm{x}$ & $0.86 *$ \\
\hline $\operatorname{Mg}\left(\operatorname{dag~kg}^{-1}\right)$ & 0.17 & 0.43 & 0.91 & 1.07 & 1.20 & 1.18 & 1.18 & $\mathrm{Mg}=0.377+0.2999 \mathrm{x}-0.0225^{*} \mathrm{x}^{2}$ & $0.82 *$ \\
\hline $\mathrm{S}\left(\right.$ dag kg $\left.^{-1}\right)$ & 0.51 & 0.39 & 0.33 & 0.32 & 0.26 & 0.24 & 0.18 & $S=0.406-0.0261 * x$ & $0.75 * *$ \\
\hline $\mathrm{Zn}\left(\mathrm{mg} \mathrm{kg}^{-1}\right)$ & 47 & 37 & 26 & 31 & 25 & 19 & 16 & $\mathrm{Zn}=37.038-2.4795^{*} \mathrm{x}$ & $0.70 *$ \\
\hline $\mathrm{Fe}\left(\mathrm{mg} \mathrm{kg}^{-1}\right)$ & 221 & 518 & 496 & 875 & 503 & 387 & 220 & & \\
\hline $\operatorname{Mn}\left(\mathrm{mg} \mathrm{kg}^{-1}\right)$ & 89 & 112 & 125 & 168 & 97 & 52 & 39 & & \\
\hline $\mathrm{Cu}\left(\mathrm{mg} \mathrm{kg}^{-1}\right)$ & 3 & 3 & 3 & 4 & 2 & 3 & 3 & & \\
\hline $\mathrm{B}\left(\mathrm{mg} \mathrm{kg}^{-1}\right)$ & 13 & 17 & 15 & 15 & 20 & 28 & 10 & & \\
\hline $\mathrm{Si}\left(\mathrm{mg} \mathrm{kg}^{-1}\right)$ & 50 & 110 & 170 & 130 & 80 & 50 & 70 & & \\
\hline
\end{tabular}

$*$ and ** Significant at the levels of $5 \%$ and $1 \%$ of probability by the $\mathrm{F}$ or t tests, respectively. 
two materials. This reduction may be due to the dilution effect and/or due to the reduction of its availability in the soil caused by the increase in $\mathrm{pH}$. No significant functional relationships were observed between $\mathrm{Fe}, \mathrm{Mn}, \mathrm{Cu}, \mathrm{B}$ and $\mathrm{Si}$ and doses of slag and limestone, despite the high content of some nutrients in the leaf, mainly $\mathrm{Si}$ in response to slag doses.

Content of $\mathrm{Cd}$ increased as a function of the doses of slag and limestone, but regression was significant only for the slag effect (Table 8). Contents of $\mathrm{Pb}$ and $\mathrm{Ni}$ increased significantly as doses of slag and limestone increased. No significant functional relationships were found between $\mathrm{Cr}$ and doses of slag and $\mathrm{Cd}$ and $\mathrm{Cr}$ and doses of limestone. According to McNichol \& Beckett (1985), the level considered critical for toxicity of heavy metals is $4 \mathrm{mg} \mathrm{kg}^{-1}$ of Cd, $2 \mathrm{mg} \mathrm{kg}^{-1}$ of Cr, $30 \mathrm{mg} \mathrm{kg}^{-1}$ of $\mathrm{Pb}$ and $8 \mathrm{mg} \mathrm{kg}^{-1}$ of $\mathrm{kg}^{-1}$ of $\mathrm{Ni}$. Therefore, even at the dose of $10 \mathrm{t} \mathrm{ha}^{-1}$, the contents obtained in the dry matter of corn plants are lower than those previously mentioned.

Table 8: Contents of heavy metals in dry matter of aerial part of corn plants grown in the soil incubated with increasing doses of steel slag and limestone and estimated regression equations of the effect of increasing doses of steel slag and limestone on the contents of heavy metals in the dry matter of the aerial part of corn plants

\begin{tabular}{|c|c|c|c|c|c|c|c|c|c|}
\hline Dose (t ha' $\left.\mathbf{h a}^{-1}\right)$ & $\mathbf{0}$ & 0.5 & 1 & 2 & 4 & 6 & 10 & Regression equation & $\mathbf{R}^{2}$ \\
\hline \multicolumn{10}{|c|}{ Slag } \\
\hline $\mathrm{Cd}\left(\mathrm{mg} \mathrm{dm}^{-3}\right)$ & 0.7 & 0.9 & 0.9 & 1.1 & 1.2 & 1.3 & 1.9 & $\mathrm{Cd}=0.7876+0.1058 * * \mathrm{x}$ & $0.96^{* *}$ \\
\hline $\mathrm{Cr}\left(\mathrm{mg} \mathrm{dm}^{-3}\right)$ & 0 & 0 & 0 & 0 & 0 & 0 & 0 & & \\
\hline $\mathrm{Pb}\left(\mathrm{mg} \mathrm{dm}^{-3}\right)$ & 4 & 4 & 3 & 6 & 6 & 6 & 18 & $\mathrm{~Pb}=2.4635+1.2662 * \mathrm{x}$ & $0.80 *$ \\
\hline $\mathrm{Ni}\left(\mathrm{mg} \mathrm{dm}^{-3}\right)$ & 1.0 & 1.0 & 1.0 & 2.5 & 1.5 & 2.0 & 2.9 & $\mathrm{Ni}=1.1195+0.1729 * \mathrm{x}$ & $0.64 *$ \\
\hline \multicolumn{10}{|c|}{ Limestone } \\
\hline $\mathrm{Cd}\left(\mathrm{mg} \mathrm{dm}^{-3}\right)$ & 0.7 & 1.6 & 1.7 & 1.5 & 1.6 & 1.7 & 1.9 & & \\
\hline $\mathrm{Cr}\left(\mathrm{mg} \mathrm{dm}^{-3}\right)$ & 0 & 0 & 0 & 0 & 0 & 0 & 0 & & \\
\hline $\mathrm{Pb}\left(\mathrm{mg} \mathrm{dm}^{-3}\right)$ & 4 & 4 & 3 & 6 & 6 & 6 & 18 & $\mathrm{~Pb}=7.8838+1.0985^{*} \mathrm{x}$ & $0.71 *$ \\
\hline $\mathrm{Ni}\left(\mathrm{mg} \mathrm{dm}^{-3}\right)$ & 1.0 & 1.0 & 1.0 & 2.5 & 1.5 & 2.0 & 2.9 & $\mathrm{Ni}=1.3886+0.2332 * \mathrm{x}$ & $0.66^{*}$ \\
\hline
\end{tabular}

* and ** Significant at the levels of $5 \%$ and $1 \%$ of probability by the $\mathrm{F}$ or $\mathrm{t}$ tests, respectively.

\section{CONCLUSIONS}

Steel slag can be used as a corrective of soil acidity, but limestone provides a higher $\mathrm{pH}$ increase over time;

Steel slag is also important for the supply of $\mathrm{P}$, micronutrients and silicon to the soil, but has lower $\mathrm{Mg}$ contents than limestone;

At doses of up to $10 \mathrm{tha}^{-1}$, the levels of heavy metals in the soil increase with the application of slag, but remain below levels considered critical for agriculture;

The heavy metal contents found in the dry matter of corn plants are similar with the application of both slag and limestone and lower than the critical levels for the toxicity of these elements in most plants;

Slag and the limestone present similar effect for the dry matter production of corn plants.

\section{REFERENCES}

Alcarde JC (2005) Corretivos da acidez dos solos: características e interpretações técnicas. São Paulo, ANDA. 24p. (Boletim Técnico).

Arcelor mittal tubarão (2016) Escória de aciaria LD. Disponível em: <http://tubarao.arcelormittal.com/produtos/co_produtos/ catalogo_produtos/escoria_aciaria_ld/introducao.asp. Acessado em: 16 de maio de 2016
Cetesb - Companhia de Tecnologia de Saneamento Ambiental (2005) Decisão da Diretoria $N^{\circ} 195$, de 23 de novembro de 2005. Disponível em: <http//www.cetesb.sp.gov.br/solo/relatórios/tabela valores 2005.pdf.>. Acessado em 23 de outubro de 2014.

Corrêa JC, Büll LT, Crusciol CAC, Marcelino R \& Mauad M (2008) Correção da acidez e mobilidade de íons em Latossolo com aplicação superficial de escória, lama cal, lodos de esgoto e calcário. Pesquisa Agropecuária Brasileira, 43:411419 .

Corrêa JC, Büll LT, Paganini WS \& Guerrini IA (2007) Disponibilidade de metais pesados em Latossolo com aplicação superficial de escória, lama cal, lodos de esgoto e calcário. Pesquisa Agropecuária Brasileira, 42:1307-1317.

Embrapa (1997) Manual de métodos de análise de solo. $2^{\mathrm{a}}$ ed. Rio de Janeiro, Ministério da Agricultura e do Abastecimento. $212 \mathrm{p}$.

Embrapa (2009) Manual de análises químicas de solos, plantas e fertilizantes. $2^{\mathrm{a}}$ ed. Brasília-DF, Embrapa Informações Tecnológicas. $627 \mathrm{p}$.

Korndörfer AP, Grisoto E \& Vendramim JD (2011) Induction of insect plant resistance to the spittlebug Mahanarva fimbriolata Stål (Hemiptera: Cercopidae) in sugarcane by silicon application. Neotropical Entomology, 3:387-392.

Lima MA, Castro VF, Vidal JB \& Enéas-Filho J (2011) Aplicação de silício em milho e feijão-de-corda sob estresse. Revista Ciência Agronômica, 42:398-403.

McNichol RD \& Beckett PHT (1985) Critical tissue concentration of potentially toxic elements. Plant and Soil, 85:107-129. 
Ministério da Agricultura, Pecuária e Abastecimento (1988) Análise de corretivos, fertilizantes e inoculantes: métodos oficiais Secretaria Nacional de Defesa Agropecuária. Brasília, Laboratório Nacional de Referência Vegetal. 104p.

Prado RM \& Fernandes FM (2000) Escória de siderurgia e calcário na correção da acidez do solo cultivado com cana-de-açúcar em vasos. Scientia Agricola, 57:739-744.

Prado RM \& Fernandes FM (2003) Efeito residual da escória de siderurgia como corretivo da acidez do solo na soqueira da canade-açúcar. Revista Brasileira de Ciência do Solo, 27:287-296.

Prado RM, Fernandes FM, Cautinho ELM, Roque CG \& Villar MLP (2002) Avaliação da escória de siderurgia e de calcários como corretivos da acidez do solo no cultivo da alface. Pesquisa Agropecuária Brasileira, 37:539-546.
Prezotti LC \& Martins AG (2012) Efeito da escória de siderurgia na química do solo e na absorção de nutrientes e metais pesados pela cana-de-açúcar. Revista Ceres, 59:427-432.

Ramos FM, Polisseni AE \& Freesz JWS (2016) Gestão Ambiental da escória de aciaria. Portal Met@lica Construção Civil. Disponível em: <http://wwwo.metalica.com.br/gestao-ambiental-daescoria-de-aciaria. Acessado em: 17 de maio de 2016.

Ribeiro Júnior JI \& Melo ALP (2009) Guia prático para utilização do SAEG. $1^{\mathrm{a}}$ ed. Viçosa, Folha Artes Gráficas. 288 p.

Winslon MD (1992) Silicon, disease resistance, and yield of rice genotypes under upland cultural conditions. Crop Science, 32:1208-1213. 